\title{
EVALUASI SEDIAAN MASKER GEL PEEL-OFF KOMBINASI EKSTRAK DAUN MANGGA BACANG (Mangifera foetida) DAN DAUN SALAM (Syzygium polyanthum)
}

\author{
Kony Putriani ${ }^{1}$, Dini Mardhiyani ${ }^{2}$, Lovera Anggraini ${ }^{3}$ \\ 1,2,3 Universitas Abdurrab, Pekanbaru, Riau \\ Email Korespondensi : konyputriani@univrab.ac.id
}

\begin{abstract}
ABSTRAK
Daun Mangga bacang dan daun salam merupakan tanaman yang bisa digunakan sebagai bahan obat tradisional sebagai antibakteri alami yang dipercaya membantu menghilangkan jerawat. Beberapa penelitian sebelumnya juga dilaporkan bahwa daun mangga bacang dan daun salam memiliki aktivitas terhadap bakteri Staphylococcus aureus, Escherichia coli dan Salmonella typhi. Penelitian ini bertujuan untuk mengetahui hasil evaluasi sediaan masker gel peel-off yang memenuhi syarat. Metode pengujian meliputi uji organoleptis, uji $\mathrm{pH}$, viskositas, uji homogenitas dan uji daya sebar. Hasil pengujian menunjukkan bahwa F1 dan F2 merupakan formula terbaik dengan karakteristik gel berwarna hijau kehitaman, bau khas daun mangga bacang dan daun salam, viskositas $1129 \mathrm{cPs}$ dan $1135 \mathrm{cPs}, \mathrm{pH}$ 4,4 dan 4,5. Uji daya sebar 5,1 cm dan $5,7 \mathrm{~cm}$ serta uji homogenitas pada masker gel peel off yaitu homogen, tidak terdapat serat, gumpalan-gumpalan maupun perbedaan warna saat dioleskan pada kaca objek transparan.
\end{abstract}

Kata kunci : Evaluasi Masker gel, peel-off, Mangifera foetida, Syzygium polyanthum. 


\title{
EVALUATION OF THE PEEL-OFF GEL MASK PREPARATION COMBINATION OF MANGO BACANG (Mangifera foetida) AND BAY LEAF EXTRACT (Syzygium polyanthum)
}

\begin{abstract}
Mango Bacang leaves and bay leaves are plants that can be used as ingredients in traditional medicine as natural antibacterials which are believed to help get rid of acne. Several previous studies also reported that Bacang mango leaves and bay leaves have activity against Staphylococcus aureus, Escherichia coli and Salmonella typhi bacteria. This study aims to determine the evaluation results of peel-off gel mask preparations that meet the requirements. The test methods include organoleptic test, pH test, viscosity, homogeneity test and dispersion test. The test results showed that F1 and F2 were the best formulas with the characteristics of a green-black gel, a characteristic odor of mango Bacang and bay leaves, a viscosity of 1129 cPs and 1135 cPs, pH 4.4 and 4.5. The dispersion test was $5.1 \mathrm{~cm}$ and $5.7 \mathrm{~cm}$ and the homogeneity test on the peel off gel mask was homogeneous, there were no fibers, lumps or differences in color when applied to a transparent slide.
\end{abstract}

Keywords: Peel-off gel mask evaluation, Mangifera foetida, Syzygium polyanthum.

\section{PENDAHULUAN}

Munculnya jerawat bisa disebabkan oleh beberapa faktor seperti lingkungan dan kebiasaan sehari-hari kita yang buruk, perubahan iklim, virus, bakteri, alergi daya tahan tubuh dan sebagainya (Pardiansyah, 2015). Jerawat adalah kelainan berupa peradangan pada lapisan pilosebaseus yang disertai penyumbatan dan penimbunan bahan keratin yang dipicu oleh bakteri Staphylococcus aureus ( Arista Yuni et al, 2013). Tanaman yang menjadi pilihan untuk dilakukan penelitian adalah daun mangga bacang dan daun salam. Daun mangga bacang dan daun salam sudah dilakukan penelitian sebagai aktivitas anti bakteri, sehingga bisa dilakukan penelitian selanjutnya dengan mengkombinasikan kedua tanaman tersebut menjadi suatu 
sediaan sebagai aktivitas anti bakteri yaitu sediaan masker gel peel-off. Beberapa penelitian sebelumnya sudah membuktikan bahwa kandungan zat aktif dari daun mangga bacang dan daun salam memberikan aktivitas sebagai anti bakteri.

Ekstrak etanol daun mangga bacang mempunyai aktivitas anti bakteri pada bakteri propionibacterium acnes dengan konsentrasi hambat minimumnya sebesar $62.5 \mathrm{mg} / \mathrm{ml}$, sedangkan konsentrasi maksimalnya sebesar $200 \mathrm{mg} / \mathrm{ml}$ (Gita amalia, 2016) Ekstrak etanol daun mangga bacang (Mangifera foetida L) juga memiliki zat aktif alkaloid, fenol, tanin, flavonoid, saponin dan telah dilakukan penelitian yang memiliki aktivitas antibakteri terhadap Staphylococcus aureus dan Escherichia coli (Nuryanto, 2014 ; Rahmawanty et al, 2015). Selanjutnya pada daun salam menurut penelitian (Agus Evendi, 2017) zat aktif yang terkandung dalam ekstrak daun salam (Syzygium polyanthum) seperti alkaloid, flavonoid, saponin, tannin dan steroid, memiliki persentase daya hambat relatif terhadap bakteri salmonella typhi dibandingkan dengan kontrol positif tertinggi pada konsentrasi $400 \mu \mathrm{g} /$ well yaitu sebesar $67 \%$ dan persentase daya hambat relatif terhadap bakteri Escherichia coli dibandingkan dengan kontrol positif tertinggi pada konsentrasi $200 \mu \mathrm{g} /$ well yaitu sebesar $47 \%$.

Masker gel peel-off memiliki kelebihan pada penggunaannya yaitu mudah dilepas seperti membran elastis (Rahmawanty et al, 2015). Masker ini mampu meningkatkan hidrasi pada kulit memperbaiki serta merawat kulit wajah dari masalah keriput, penuaan, jerawat, dan bisa digunakan untuk mengecilkan pori, membersihkan serta melembabkan kulit, memberikan manfaat dalam merelaksasi otot-otot wajah, sebagai pembersih, penyegar, pelembab dan pelembut untuk kulit wajah ( Grace et al 2015 ; Velasco, 2014 ; Vieria et al 2009). Penelitian ini bertujuan untuk mengetahui hasil evaluasi sediaan masker gel peel-off yang memenuhi persyaratan farmasetika.

\section{METODE PENELITIAN}

\section{ALAT DAN BAHAN}

Bahan yang digunakan adalah ekstrak etanol daun mangga bacang dan daun salam, etanol 96\%, Polivinil alcohol, Hidroksipropil metilselulosa, 
Metil paraben, Propilen glikol, masker gel peel off serta melakukan Aquades. Sedangkan alat yang evaluasi pada sediaan masker gel peel digunakan adalah viskometer, alat-alat off yaitu uji organoleptis, uji gelas, batang pengaduk, cawan porselin, $\quad \mathrm{pH}$,viskositas, uji homogenitas dan uji kaca objek, transparan, timbangan analitik, sudip, pH meter, mortir, stamper.

\section{PROSEDUR KERJA}

Ekstraksi Daun Mangga Bacang dan

\section{Daun Salam}

Daun mangga bacang dan daun salam yang dibuat simplisia dan selanjutnya dilakukan tahap maserasi atau perendaman dengan etanol 96\%, untuk mendapatkan ekstrak kental dilakukan rotary terlebih dahulu menggunakan alat rotary evaporator hingga didapatkan ekstrak kental (Marlinda et al, 2012). Setelah didapatkan ekstrak daun mangga bacang dan daun salam langkah berikutnya dilakukan pembuatan formulasi sediaan daya sebar.

Pembuatan Sediaan Masker gel Peel Off Ekstrak Daun Mangga Bacang dan Daun Salam.

Ekstrak daun mangga bacang dan daun salam masing-masing dilarutkan dalam akuades. Polivinil alcohol (PVA) (Bahan A) dikembangkan dengan akuades hangat dan diaduk. HPMC (Bahan B) dikembangkan dalam akuades. Sedangkan metil paraben (Bahan C) dilarutkan ke dalam propilen glikol. Kemudian ditambah etanol $96 \%$ dan diaduk sampai homogen Selanjutnya ditambahkan akuades sampai mencapai bobot 100 gram. Sediaan masker gel peel-off ini kemudian dimasukkan kedalam wadah tertutup rapat. 
Tabel 1. Formulasi sediaan masker gel peel-off ekstrak daun mangga bacang dan daun salam. Sumber: (Septiani et al, 2011) .

\begin{tabular}{|c|c|c|c|c|c|}
\hline \multirow[t]{2}{*}{ No } & \multirow[t]{2}{*}{ Bahan } & \multicolumn{4}{|c|}{ Persen bahan dalam tiap 100 gram } \\
\hline & & F0 & F1 & $\mathrm{F} 2$ & F3 \\
\hline 1 & Polivinil alcohol & 12 & 12 & 12 & 12 \\
\hline 2. & $\begin{array}{l}\text { Hidroksipropil } \\
\text { metilselulosa }\end{array}$ & 1 & 1 & 1 & 1 \\
\hline 3. & Metil paraben & 0.2 & 0.2 & 0.2 & 0.2 \\
\hline 4. & Propilen glikol & 10 & 10 & 10 & 10 \\
\hline 5. & $\begin{array}{l}\text { Ekstrak daun } \\
\text { mangga bacang }\end{array}$ & - & 5 & 10 & 15 \\
\hline 6. & Ekstrak daun salam & - & 5 & 10 & 15 \\
\hline 7. & Etanol 96\% & 15 & 15 & 15 & 15 \\
\hline 8. & Aquades & Ad & Ad & Ad & Ad 100 \\
\hline & & 100 & 100 & 100 & \\
\hline
\end{tabular}

\section{Evaluasi Sediaan Masker gel Peel Off} Ekstrak Daun Mangga Bacang dan Daun Salam.

\section{Uji Organoleptis}

Uji organoleptis dilakukan dengan melihat bentuk dan warna serta mencium bau dari bentuk sediaan masker gel peel off ekstrak daun mangga bacang dan daun salam.

\section{Uji pH}

Pengukurun $\mathrm{pH}$ diawali dengan melakukan kalibrasi $\mathrm{pH}$ meter. Kalibrasi dilakukan menggunakan larutan buffer $\mathrm{pH}$ 4 dan $\mathrm{pH}$ 10. Pengukuran $\mathrm{pH}$ dilakukan dengan mencelupkan elektroda ke dalam 1 gram sediaan masker gel peel off 5\% (F1), $10 \%(\mathrm{~F} 2)$ dan 15\% (F3) serta $0 \%(\mathrm{~F} 0)$ mengacu pada metode (Apriyanto et $a$, 1989). 


\section{Uji Viskositas}

Pengukuran viskositas dilakukan menggunakan viskometer Brookfield spindel no. 6 Masker gel dimasukkan ke dalam wadah gelas kemudian spindel yang telah dipasang diturunkan sehingga batas spindel tercelup ke dalam masker. Kecepatan putar yang digunakan pada uji viskositas ini adalah $30 \mathrm{rpm}$. Hasil pengukuran nilai viskositas tersebut akan didapat angka yang ditampilkan pada monitor viscometer, dinyatakan dalam centipoise, pengukuran viskositas ini dilakukan pada suhu kamar (Garg et al, 2010).

\section{Uji Homogenitas}

Masker yang akan diamati ditimbang sebanyak 1 gram dan dioleskan pada kaca objek yang bersih dan kering sehingga membentuk suatu lapisan tipis. Kaca objek kemudian ditutup dengan kaca preparat. Masker gel peel off menunjukkan susunan yang homogen apabila tidak terlihat adanya butiran kasar, tekstur tampak rata dan tidak menggumpal, uji homogenitas fisik mengacu pada metode (Ansel et al, 1989).

\section{Uji Daya Sebar}

Pengukuran daya sebar masker gel peel off sebanyak 1 gr, sediaan diletakkan ditengah 2 cawan petri yang telah dibalik dan dilapisi plastic transparan dibawah. Lalu tambahkan beban di atasnya seberat 125 gr, didiamkan 1 menit. Kemudian ukur diameter gel menggunakan penggaris catat daya sebarnyadan dilakukan sebanyak 3 kali.

\section{Analisa Data}

Hasil dari optimasi formula masker gel peel off dapat dilakukan dengan pengujian kualitas fisik sediaan masker gel peel off terhadap data yang diperoleh pada pengamatan organoleptis, nilai $\mathrm{pH}$, viskositas, homogenitas, serta daya sebar, yang disajikan dalam bentuk tabel.

\section{HASIL DAN PEMBAHASAN}

\section{Hasil Pembuatan Ekstrak Daun}

Mangga Bacang dan Daun Salam

Ekstrak yang didapatkan untuk daun mangga bacang sebanyak 191,14 gram dan ekstrak daun salam sebanyk 131gram. Ekstrak yang dihasilkan memiliki karakteristik warna hijau kehitaman, rasa pahit, dan aroma khas daun mangga bacang dan daun salam. Hasil uji fitokimia Ekstrak etanol daun mangga bacang (Mangifera foetida L.) mengandung alkaloid, fenol, tanin, flavonoid, steroid, saponin dan telah diteliti memiliki aktivitas antibakteri terhadap Staphylococcus aureus dan 
Escherichia coli(Nuryanto, 2014 ; Rahmawanty et al, 2015).

Evaluasi Sediaan Masker Gel Peel Off Ekstrak Daun Mangga Bacang dan Daun Salam

Pembuatan formulasi sediaan masker gel digunakan basis polivinil alcohol, Hidroksipropil metilseluosa, metil paraben, propilen glikol, etanol $96 \% \mathrm{v} / \mathrm{v}$ dan aquadest. Pada tahap pembuatan sediaan dengan basis polivinil alcohol, sediaan mempunyai kelebihan yaitu tekstur gel lembut dan elastis setelah penggunaan.pada formulasi sediaan, dibuat kombinasi zat aktif yaitu ekstrak etanol daun mangga bacang dan ekstrak etanol daun salam dengan beberapa konsentrasi. PVA berfungsi untuk memberikan efek peel off karena memiliki sifat adhesive sehingga dapat membentuk lapisan film yang mudah dikelupas setelah kering ( Birck et al 2014). Konsentrasi PVA merupakan faktor penting yang berpengaruh terhadap kinerja pembentukan film dalam masker wajah peel off ( Beringhs et al 2013).

HPMC berfungsi sebagai bahan pembentuk gel. Propilen glikol berfungsi sebagai humektan untuk menjaga kestabilan sediaan dengan mengabsorbsi lembab dari lingkungan dan mengurangi penguapan air dari sediaan masker. Selain berfungsi untuk menjaga kestabilan sediaan, humektan juga dapat mempertahankan kelembaban kulit, sehingga kulit tidak kering ( Barel et al 2009, Martin et al 1993). Metil paraben berfungsi sebagai pengawet (Depkes RI, 1979).

\section{Uji organoleptis}

Uji organoleptis dilakukan dengan melihat bentuk dan warna serta mencium bau dari sediaan masker gel peel off berdasarkan hasil uji organoleptis pada F0 berwarna putih hal ini dikarenakan F0 tidak mengandung ekstrak, dan hanya mengandung bahan-bahan tambahan saja. Sedangkan untuk F1, F2, F3 warna masker gel peel off yang dihasilkan berwarna hijau kehitaman hal ini dikarenakan pada F1, F2, F3 mengandung ekstrak daun mangga dan daun salam, rasa pahit serta beraroma khas daun mangga bacang dan daun salam. 
Nilai pH

Pengukuran nilai $\mathrm{pH}$ dilakukan untuk mengetahui nilai $\mathrm{pH}$ suatu sediaan. Nilai pH keempat formula sediaan masker gel peel off berkisar 4,4-6,0 yaitu F0 6.0, F1 4.5, F2 4.4, F3 4.5. Hasil nilai $\mathrm{pH}$ keempat sediaan sesuai dengan rentang $\mathrm{pH}$ kulit manusia. Trenggono dan latifah melaporkan rentang $\mathrm{pH}$ kulit berkisar antara 4,5-6,5 (Tranggono et al, 2007). Hasil pengukuran $\mathrm{pH}$ dilihat pada tabel 2

Tabel 2. Hasil Pengukuran nilai $\mathrm{pH}$ pada sediaan masker gel peel off

\begin{tabular}{cc}
\hline Formula & $\mathrm{pH}$ \\
\hline F0 & 6.0 \\
F1 & 4.5 \\
F2 & 4.4 \\
F3 & 4.5 \\
\hline
\end{tabular}

\section{Nilai viskositas}

Tujuan uji viskositas untuk menentukan nilai kekentalan suatu zat. Semakin kental suatu sediaan maka semakin kecil kecepatan alirannya (Syamsuni, 2005). Nilai viskositas berbanding terbalik dengan daya sebar, artinya semakin tinggi viskositas maka semakin kecil daya sebarnya. Hasil uji viskositas masker gel peel-off ekstrak daun mangga bacang dan ekstrak daun salam memenuhi syarat standar nilai viskosistas. nilai viskositas gel yang baik berada pada rentang 2000-4000 cps. Semakin kental suatu sediaan maka semakin kecil kecepatan alirannya (Garg et al , 2002). Kekentalan suatu sediaan dapat dipengaruhi oleh adanya penambahan zat 118 aktif yang dapat mempengaruhi nilai viskositas terhadap masker gel yang dibuat. Nilai viskositas masker gel peel off ekstrak daun mangga bacang dan ekstrak daun salam pada Formula 0, 1, 2, dan 3 berturut-turut 273.3, 1129, 1135, 12490 cps.

Berdasarkan hasil nilai viskositas pada tabel diatas F0-F2 memenuhi rentang viskositas daro 2000-4000 cps namun pada F3 tidak masuk rentang viskositas dikarenakan pada saat melakukan pengerjaan formualsi masker gel terjadi kesalahan dalam menghitung air yang dibutuhkan untuk membuat sediaan masker gel peel off sehingga gel yang di hasilkan tidak sesuai yang diingankan dan tidak sebagus seperti F1 https://doi.org/10.33759/jrki.v4i1.218 
dan F2. Hasil nilai viskositas dilihat pada

tabel 3 .

Tabel 3. Hasil nilai viskositas pada sediaan masker gel peel off

\begin{tabular}{ccc}
\hline Formula & Centipoise & $\begin{array}{c}\text { Keterangan ( Viskositas memenuhi syarat } \\
\text { 2000-4000 Centipoise) }\end{array}$ \\
\hline F0 & 273.3 & Memenuhi Syarat \\
F1 & 1129 & Memenuhi Syarat \\
F2 & 1135 & Memenuhi Syarat \\
F3 & 12490 & Tidak Memenuhi Syarat \\
\hline
\end{tabular}

\section{Homogenitas}

Tujuan uji homogenitas untuk melihat masker saat dioleskan. Hasil pengujian efektifitas merata atau tidaknya homogenitas disajikan pada gambar 1. pencampuran bahan-bahan pada formula
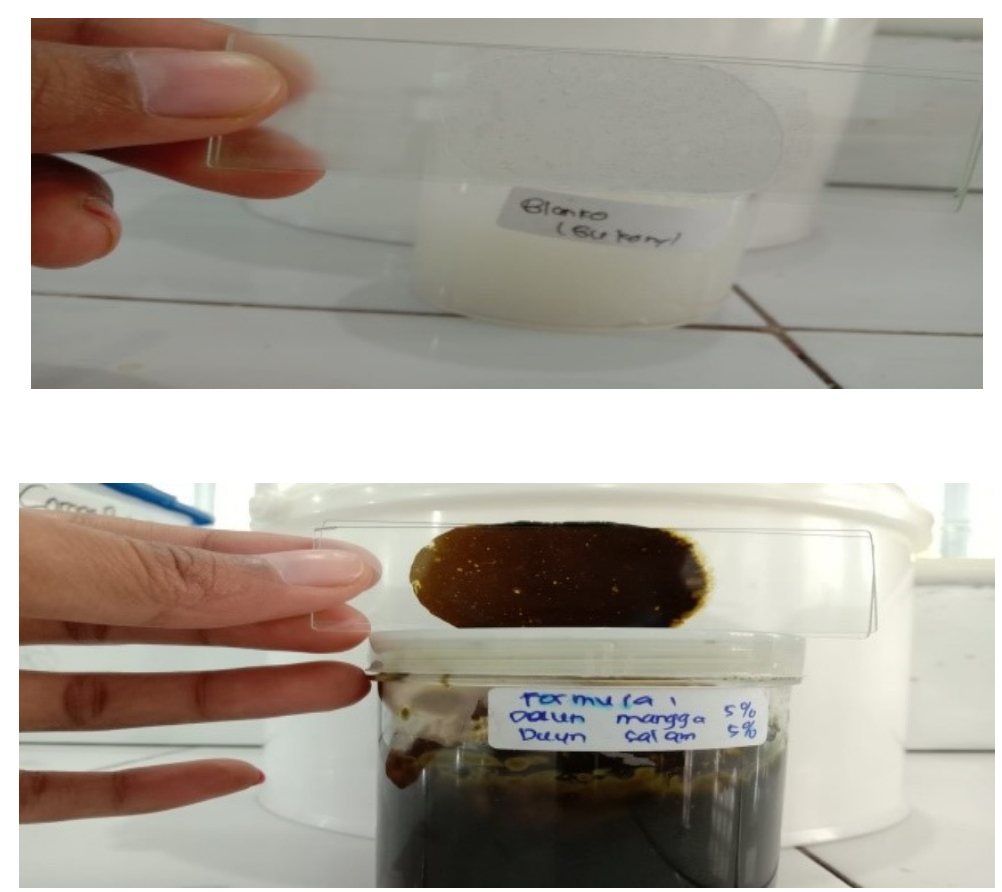

Gambar 1. Hasil uji homogenitas 
Menunjukkan bahwa masker gel peel off yang ditambahkan ekstrak daun mangga bacang dan daun salam $(0 \%$, $5 \%, 10 \%)$ adalah homogen, tidak terdapat serat, gumpalan-gumpalan maupun perbedaan warna saat dioleskan pada kaca objek transparan.. (Armandany \& Hasnawati , 2017) melaporkan bahwa homogenitas ditandai dengan tidak adanya agregasi partikel sekunder. Pada penelitian
(Juwita, 2011) melaporkan bahwa homogenitas terjadi apabila zat aktif bercampur denga basis sehingga tidak terjadi penggumpalan. Pemeriksaan homogenitas dilakukan untuk melihat homogenitas sediaan masker gel peel off pada saat dioleskan, yang ditandai dengan tidak adanya serat atau partikel (Voigt, 1995).

\section{Daya sebar}

Tabel 4. Hasil Uji Daya Sebar pada sediaan masker gel peel off

\begin{tabular}{ccc}
\hline Formula & Daya Sebar $(\mathrm{cm})$ & $\begin{array}{c}\text { Keterangan (Daya Sebar Memenuhi } \\
5-7 \mathrm{~cm})\end{array}$ \\
\hline F0 & 5 & Memenuhi Syarat \\
F1 & 5.1 & Memenuhi Syarat \\
F2 & 5.7 & Memenuhi Syarat \\
F3 & 2.7 & Tidak Memenuhi Syarat \\
\hline
\end{tabular}

Hasil pengujian daya sebar masker gel peel off ekstrak daun mangga bacang dan daun salam pada tabel 4 didapatkan daya sebar keempat formula berkisar 2$5.7 \mathrm{~cm}$. Dapat dilihat bahwa formula III memiliki diameter daya sebar yang kecil karena pada saat pembuatan sediaan formula III dilakukan peleburan kembali sehingga viskositasnya besar. Sesuai dengan teori (Trilestari, 2002; Zulkarnain et al, 2013) bahwa semakin tinggi viskositas maka semakin turun daya penyebarannya begitu pula sebaliknya.

Tujuan uji daya sebar untuk mengetahui daya penyebaran gel pada kulit yang sudah diole

skan. Nilai daya sebar gel yang baik yaitu antara 5-7 cm (Martin et al, 1993). Semakin tinggi konsentrasi gelling agent yang digunakan maka akan terjadi penurunan nilai daya sebar pada masingmasing formula. Penurunan nilai daya 
sebar ini disebabkan karena perbedaan konsentrasi HPMC pada masing-masing formula menyebabkan perbedaan viskositas gel yang dihasilkan, dimana viskositas gel berbanding terbalik dengan daya sebar yang dihasilkan. Semakin tinggi konsentrasi gelling agent yang digunakan maka akan meningkatnya tahanan gel untuk mengalir dan menyebar (Martin et al, 1993) .

\section{KESIMPULAN}

Hasil formulasi yang baik yaitu pada formulasi 1 dan formulsi 2 (F1 dan F2), perlu adanya variasi konsentrasi formulasi agar hasil formulasi masker gel peel off yang dihasilkan lebih bagus.

\section{UCAPAN TERIMAKASIH}

Pada kesempatan ini, peneliti ingin mengucapkan terima kasih kepada berbagai pihak yang telah membantu terwujudnya penelitian ini :

1. Lembaga Ristekdikti yang memberikan dana Hibah penelitian Nomor Kontrak LPPM-Peneliti Nomor: 016/LPPM/KPDP/IV/2020 tanggal 13 April 2020.

2. Lembaga Penelitian dan Pengabdian Universitas Abdurrab Pekanbaru, Riau.

\section{DAFTAR PUSTAKA}

Arista, Yuni ., Kumesan, Paulina V. Y. Yamlean., Hamidah S. Supriati. 2013. Formulasi dan Uji Aktivitas Gel Anti Jerawat Ekstrak Umbi Bakun (Crinum Asiaticum

L) Terhadap Bakteri Staphylococcus Aureus Secara In Vitro. Jurnal Ilmiah Farmasi UNSRAT Vol. 2 No. 02.

Agus Evendi. 2017. Uji Fitokimia Dan Anti Bakteri Ekstrak Daun Salam (Syzygium polyanthum) Terhadap Bakteri Salmonella typhi dan Escherichia coli Secara in vitro. Analis Kesehatan, Poltekkes Kemenkes Kaltim, Mahakam Medical Laboratory Technology Journal. II (1): 1-9.

Armadany FI, Hasnawati MS. 2017. Formulasi sediaan masker gel peel off antioksidan dari ekstrak sari tomat (Solanum lycopersicum L.) Majalah Farmasi, Sains, dan Kesehatan. 1(2):29-32.

Birck, C., S. Degoutin, N. Tabary, V. Miri, and M. Bacquet. 2014. New https://doi.org/10.33759/jrki.v4i1.218 
crosslinked cast films based on poly (vinyl alcohol): preparation and physico-chemical properties. Express Polymer Letters. 8 (12): 941-952.

Beringhs, A.O., M.R. Julia, K.S. Hellen, M.B. Rosane, and S. Diva. 2013. Green clay and aloe vera peel-off facial masks: response surface methodology applied to the formulation design. AAPS Pharm Sci Tech. 14 (1): 445-455.

Barel, A. O., M. Paye, dan H. I. Maibach. 2009. Handbook of Cosmetic Science and Technology. Third Edition. New York: Informa Healthcare USA, Inc. Pp. 233, 261- 262 .

Gita Amalia Asikin, Muhamad Agus Wibowo, Effiana , 2016. Uji Aktivitas Antibakteri Ekstrak

Etanol Daun Mangga Bacang (Mangifera foetida L.) terhadap Propionibacterium acnes secara in vitro. Program Studi Pendidikan Dokter, Program Studi Kimia, FMIPA UNTAN 3 Departemen Pre Klinik Mikrobiologi Medik, FK
UNTAN. Jurnal Cerebellum. Volume 2 No. 2.

Garg A, Deepika A, Garg S, Singla AK. 2010. Spreading of semisolid formulation.

USA:

\section{Pharmaceutical}

Technology. Pp 84-104

Grace FX, Darsika C, Sowmya KV, Suganya K, Shanmuganathan S. 2015. Preparation and evaluation of herbal peel off face mask. American Journal of PharmTech Research. 5(4): 33-336.

Juwita NK, Djajadisastra J, Azizahwati. 2011. Uji penghambatan tirosinase dan stabilitasfisik sediaan krim pemutih yang mengandungekstrak kulit batang nangka(Artocarpus heterophyllus). Jurnal Ilmu Farmasi. 8(3):17-21.

Marlinda, M., Meiskes., S. \& Audym, D. W. 2012. Analisis senyawa metabolit sekunder dan uji toksisitas ekstrak etanol biji alpukat (Persea Americana Mill). Universitas Sam Ratulangi. 
Jurnal Mipa Unsrat Online 1 (1) 24-28.

Nuryanto A. Uji Aktivitas Antibakteri Ekstrak Etanol Daun Mangga Bacang (Mangifera foetida L.) terhadap Escherichia coli secara In Vitro. Jurnal Mahasiswa PSPD FK Universitas

Tanjungpura. 2014; 1(1).

Pardiansyah, R. 2015. Association Between Personal Protective Equipment with the Irritant Contact Dermatitist in Scavengers. Faculty of Medicine Lampung University, Lampung. $J$ Majority Vol.4 No.4.

Rahmawanty D, Yulianti N, Fitriana M. 2015. Formulasi dan evaluasi masker wajah peel-off mengandung kuersetin dengan variasi konsentrasi gelatin dan gliserin. Media Farmasi. 12 (1): $17-32$.

Septiani, S., Wathoni, N. \& Mita, S.R. 2011. Formulasi sediaan masker gel antioksidan dari ekstrak etanol Semisolid
Formulation. Pharmaceutical Technology. Aster Publishing Corp.

Velasco, M. 2014. Short-term clinical of peeloff facial mask moisturizers. International Journal of Cosmetic Science. 36: 355-360.

Vieira RP, Fernandes AR, Kaneko TM, Consiglieri VO, Pinto CASO. 2009. Physical and physicochemical stability evaluation of cosmetic formulations containing soybean extract fermented by Bifidobacterium animalis. Brazilian Journal of Pharmaceutical Sciences. 45 (3):515-525. 